\title{
A PERFORMANCE STUDY OF HIGH-RISE BUILDING UNDER LATERAL LOAD WITH RIGID FRAME, CORE AND OUTRIGGER STRUCTURAL SYSTEMS
}

\author{
Manoj Kumar $\mathbf{M}^{1}$, B. S. Jayashankar Babu ${ }^{2}$ \\ ${ }^{I}$ M.Tech student, Department of Civil Engineering, PES College of Engineering, Mandya, Karnataka, India \\ ${ }^{2}$ Professor, Department of Civil Engineering, PES College of Engineering, Mandya, Karnataka, India
}

\begin{abstract}
In this study considered, Performance of 20 storey building under lateral load with different structural systems, such as Rigid frame, Core and Outrigger structural systems under seismic loading with seismic zone V at soil type III (soft soil) and reduction factor 5 for special RC moment-resisting frame. It is evaluated by Response Spectrum analysis for different load combinations as per IS: 1893:2002. Analysis of above mentioned structural systems are carried-out using E-TABS 2015 software. To check the performance of the building by considering following parameters such as, roof displacement, base bending moment of inner and edge columns and base core moment for core structural system and outrigger structural systems. The object of the study is to determine the degree of effectiveness of different locations of outrigger structural system to increase the performance and sustainability of the building.
\end{abstract}

Keywords: - Rigid frame system, core system, outrigger system, Response spectrum analysis and E-TABS 2015

\section{INTRODUCTION}

The increase in population and shortage of land in urban areas, leads to development of tall buildings. Such buildings are subjected to lateral loads such as seismic and wind loads play a dominant role due to their height and terrain characteristics and show greater sensitivity. By using different types of structural systems such as rigid frame system, flat slabs system, braced-frame system, shear wall system, core system, mega column, outrigger frame system, tube system etc. the lateral load resisting capacity is increased to a certain extent.

Many researchers focused on to obtain position of outrigger to control lateral displacement but, secondary needs of research like, controlling core moment and column reaction are need to studied[7]. So, an attempt is made in this paper to include column reaction and core moment which is discussed below.

\subsection{Core and Outrigger Structural System}

Core system is used in RC buildings. This system consists of a $\mathrm{RC}$ core shear wall resisting all the vertical and lateral loads, Fig -1 .

The outriggers are structural elements connecting the core to the perimeter columns at one or more levels throughout the height of the building to stiffen the structure, Fig - 1. An outrigger consists of a horizontal shear truss or shear wall or deep beams. Because the outrigger affects the interior space, they generally located at mechanical equipment floors in order not to hinder the use of normal floors. $* * *$

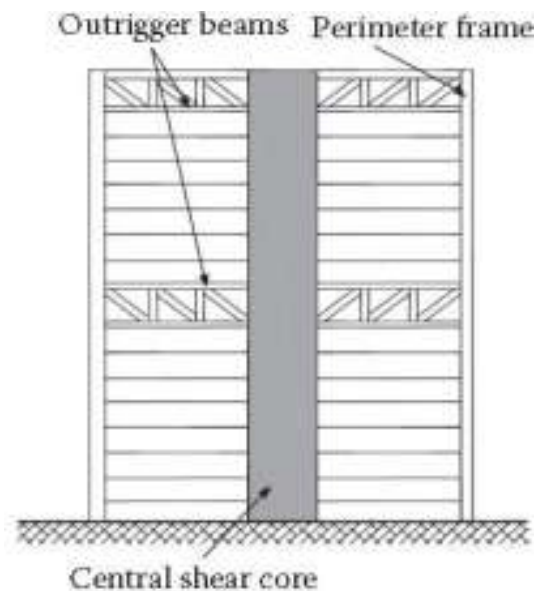

Fig 1: Core and Outrigger frame system adopted in present study (diagonal bracing type)

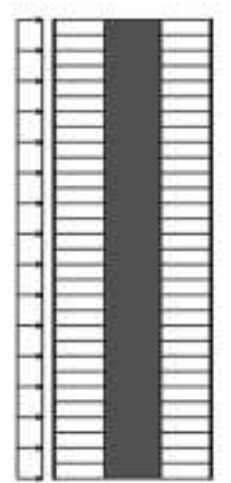

Fig 2: Effect of Outrigger on the moment when compared with core system

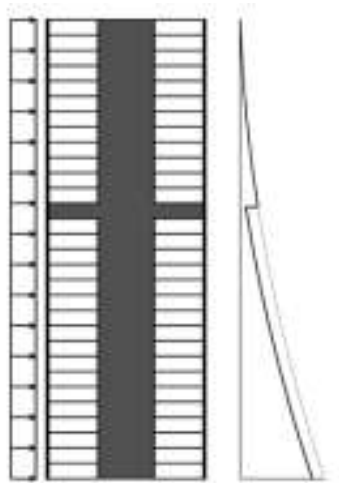


Outriggers are one of the most effective structural system in reducing the lateral deflection, shear and moment in tall buildings, Fig 2 .

Several factors affect the performance of outrigger system are, number of outrigger, type of outrigger, depth of outrigger, height of the building, type of material used to outrigger beam, shape of building, shape of the shear wall at center, intensity of lateral loads etc.

In the present study, the effect of number of outrigger system in 20 storey buildings under seismic loading as per IS1893 (part-1):2002 are considered. The overall aim is to assess the structural performance 20storeywith seismic zones $\mathrm{V}$ at soil type III as per Indian standards. So an attempt is made to controlling roof displacement, core moment and column reactions at edge and inner column. This investigation will serve as a reference for seismic resistant design of rigid frame, core and outrigger structural systems in high-rise RC buildings

\section{MODELING OF 20 STOREY REINFORCED CONCRETE BUILDING}

Modeling of 20 storey RC building describes the structural configuration of different structural system are as shown in Fig -3. Frame selected for analysis is symmetrical in plan of $42 \times 42 \mathrm{~m}$ with Centre to Centre column spacing is $6 \mathrm{~m}$. Different structural system is introduced in order to minimize the top storey displacement, core moment and column reactions at edge $\mathrm{C} 1$ and inner $\mathrm{C} 27$ columns for 20 storey building, Fig -3 . The structural configuration of buildings like material property (concrete and rebar grade) varied (material property will be same for all structural elements at that floor) i.e. 1 to 5 storey M40, 6 to 10 stoery M30 and 11 to 20 storey M25 and sectional property of column 700x1000 mm and beam 400x600 mm and storey height is $3 \mathrm{~m}$. Slab, masonry walls and shear wall thickness is assumed to be $150 \mathrm{~mm}, 200 \mathrm{~mm}$ and $250 \mathrm{~mm}$ respectively. Diagonal bracing type is adopted as outrigger beam and outrigger beam size 400x600mm.

Each building is subjected to gravity and lateral load. Wall load of $10 \mathrm{kN} / \mathrm{m}$ on floor throughout beam length, floor finish of $1.5 \mathrm{kN} / \mathrm{m}^{2}$ and live load of $2 \mathrm{kN} / \mathrm{m}^{2}$ expect roof, at roof wall load of $4 \mathrm{kN} / \mathrm{m}$ as parapet wall, floor finish of $3 \mathrm{kN} / \mathrm{m}^{2}$ and live load of $1.5 \mathrm{kN} / \mathrm{m}^{2}$. Seismic loading as per IS1893 (part1) - 2002, seismic zone V at soil type III (soft soil).Natural time period of vibration by empiricalexpression as per IS1893 (part-1) - 2002 for 20storey building is 0.833 sec. The results are noted for load combination specified as per IS codes. At present study $1.5(\mathrm{DL}+\mathrm{SDL} \pm \mathrm{EQ} \mathrm{X})$ is critical combination which results are obtained.
Table -1: Factors affecting outrigger performance

\begin{tabular}{|l|l|}
\hline Factors & Adopted at present work \\
\hline Type of outrigger & $\begin{array}{l}\text { Conventional outrigger } \\
\text { without belt truss }\end{array}$ \\
\hline Number of outrigger & $1,2,3$ and 4 \\
\hline Position of outrigger & $0.25 \mathrm{H}, 0.5 \mathrm{H}, 0.75 \mathrm{H}$ and $\mathrm{H}$ \\
\hline Depth of outrigger & $600 \mathrm{~mm}$ \\
\hline Height of building & $60 \mathrm{~m}$ \\
\hline Shape of core wall & Closed / Square \\
\hline Intensity of lateral load & Zone V as per IS1893: 2002 \\
\hline
\end{tabular}

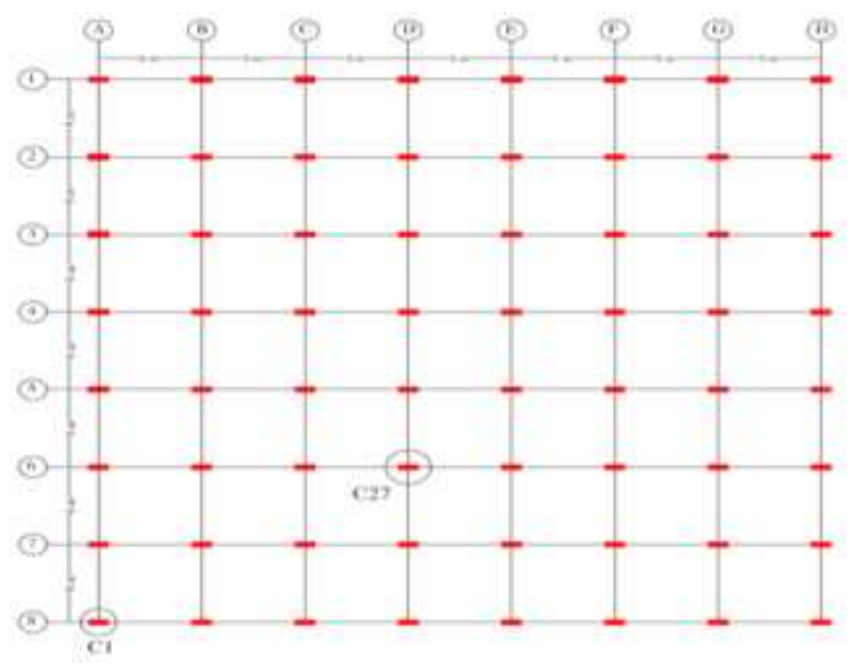

Fig - 3: Plan considered for the study and marked critical column $\mathrm{C} 1$ and $\mathrm{C} 27$

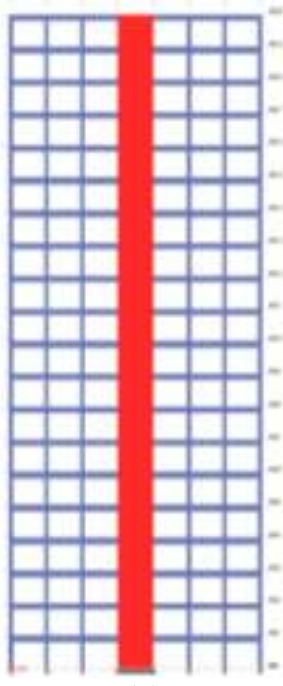

(a)

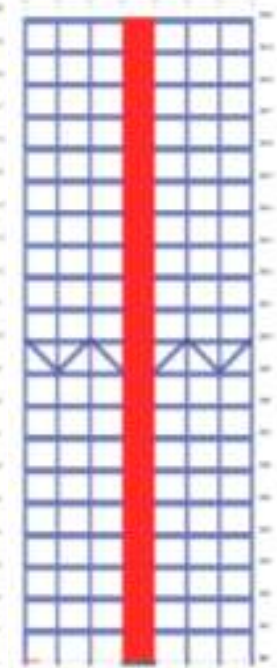

(b)

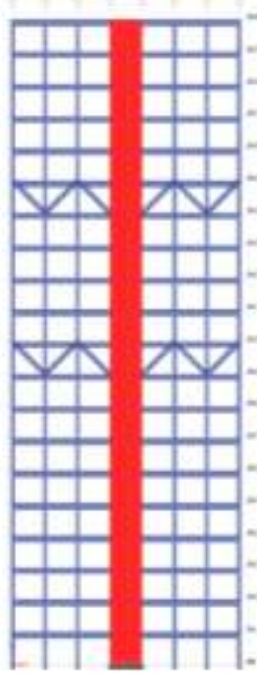

(c) 


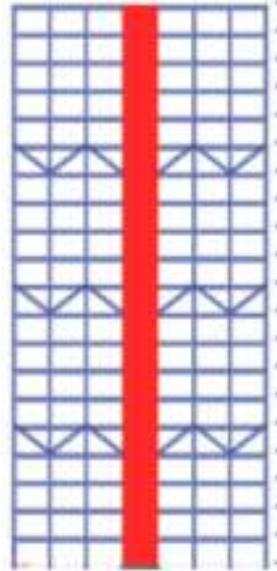

(d)

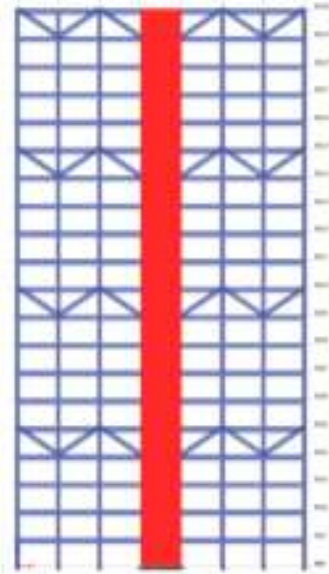

(e)
Fig - 4 : Section view at E for 20 storey core wall (a) with

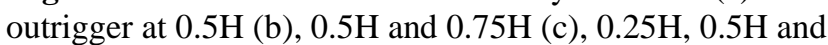
$0.75 \mathrm{H}(\mathrm{d})$ and $0.25 \mathrm{H}, 0.5 \mathrm{H}, 0.75 \mathrm{H}$ and $\mathrm{H}(\mathrm{e})$.

\subsection{Method of Analysis}

Generally following four types of analysis are used for seismic design and performance of buildings, viz linear equivalent static analysis, linear response spectrum analysis, nonlinear static pushover analysis and nonlinear time history analysis. In present study, Response spectrum analysis is used. Dynamic analysis are performed as per clause no 7.8.1 (a), IS1893 - 2002[12]. Response of building from earthquake considered by load combination as per IS456: 2000, Table 18. Modeling and analysis are carried out by ETABS-2015 software.

\section{RESULTS AND DISCUSSIONS}

In the present study roof displacement, base bending moment of inner and corner column and base moment of core in core structural system and outrigger structural system under seismic load as per IS1893 (part - 1): 2002 for seismic zone $\mathrm{V}$ and soil type III.

\subsection{Rigid frame System and Core System}

Table -2: summary of results from rigid frame and core system

\begin{tabular}{|c|c|c|c|c|c|}
\hline \multirow[t]{2}{*}{$\begin{array}{l}\text { Structural } \\
\text { system }\end{array}$} & \multicolumn{2}{|c|}{$\begin{array}{l}\text { Roof } \\
\text { displacement } \\
(\mathrm{mm})\end{array}$} & \multicolumn{2}{|c|}{$\begin{array}{l}\text { Base bending } \\
\text { moment of } \\
\text { column }(\mathrm{kN}-\mathrm{m})\end{array}$} & \multirow{2}{*}{$\begin{array}{l}\text { Base } \\
\text { core } \\
\text { moment } \\
(\mathbf{k N}-\mathbf{m}) \\
\end{array}$} \\
\hline & $\mathbf{X}$ & $\mathbf{Y}$ & C27 & C1 & \\
\hline $\begin{array}{l}\text { Rigid } \\
\text { frame }\end{array}$ & 242.8 & 261 & 2937.1 & 2797.8 & - \\
\hline Core & 191 & 199.2 & 1717.3 & 1624.9 & 422879.1 \\
\hline
\end{tabular}

\section{2 $1^{\text {ST }}$ Outrigger}

For first outrigger location is at $0.25 \mathrm{H}, 0.5 \mathrm{H}, 0.75 \mathrm{H}$ and $\mathrm{H}$. Where $\mathrm{H}$ - height of the building from base
Table -3: summary of results from $1^{\text {st }}$ outrigger system at different location

\begin{tabular}{|l|l|l|l|l|l|}
\hline \multirow{2}{*}{$\begin{array}{l}\text { Position } \\
\text { of } \\
\text { outrigger }\end{array}$} & \multicolumn{2}{|l|}{$\begin{array}{l}\text { Roof } \\
\text { displacement } \\
\text { (mm) }\end{array}$} & $\mathbf{X}$ & Y & \multicolumn{2}{|l|}{$\begin{array}{l}\text { Base bending } \\
\text { moment of } \\
\text { column (kN-m) }\end{array}$} & $\begin{array}{l}\text { Base } \\
\text { Core } \\
\text { moment } \\
\text { (kN-m) }\end{array}$ \\
\hline $\mathbf{0 . 2 5 H}$ & 168.9 & 175.8 & 1617.8 & 1531.1 & 346916.2 \\
\hline $\mathbf{0 . 5 H}$ & 165.5 & 173.8 & 1700.5 & 1609.3 & 406644 \\
\hline $\mathbf{0 . 7 5 H}$ & 170.5 & 178.3 & 1724.7 & 1632 & 425639 \\
\hline $\mathbf{H}$ & 179.5 & 187.3 & 1721.3 & 1628.6 & 423929.9 \\
\hline
\end{tabular}

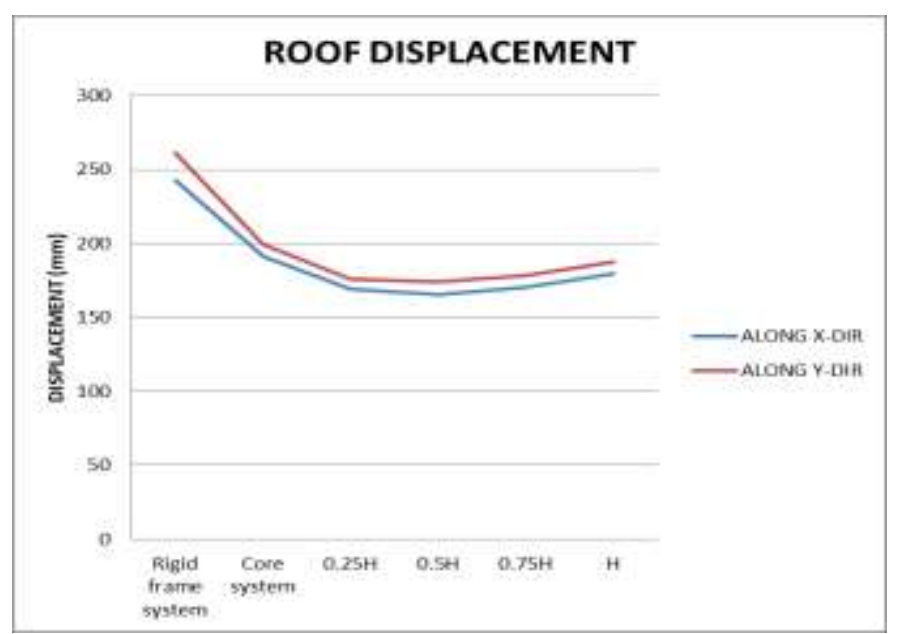

Chart -1: Roof displacement along $\mathrm{X}$ and $\mathrm{Y}$ direction for rigid frame system, core system and $1^{\text {st }}$ outrigger at $0.25 \mathrm{H}$, $0.5 \mathrm{H}, 0.75 \mathrm{H}$ and $\mathrm{H}$

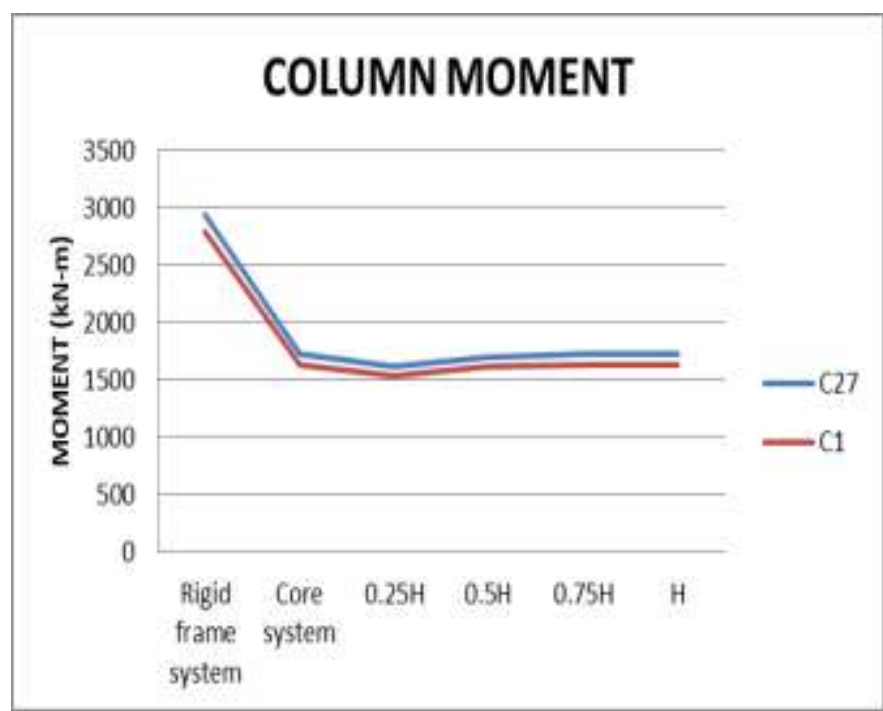

Chart -2: Column moment for C27 and C1 columns 


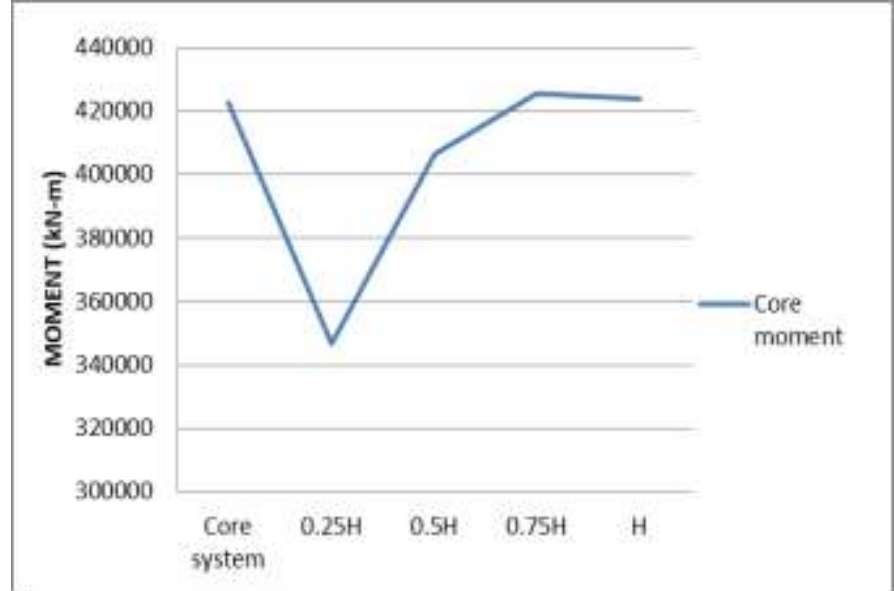

Chart -3: Core moment for Core and $1^{\text {st }}$ outrigger at $0.25 \mathrm{H}$, $0.5 \mathrm{H}, 0.75 \mathrm{H}$ and $\mathrm{H}$

1. From chart -1 , about $21.33 \%, 30.43 \%, 31.83 \%, 29.77 \%$ and $26.07 \%$ reduction in roof displacement along $\mathrm{X}$ direction and $23.67 \%, 32.64 \%, 33.4 \%, 31.68 \%$ and $28.23 \% \%$ reduction in roof displacement along $\mathrm{Y}$ directionis observed for core, $1^{\text {st }}$ outrigger at $0.25 \mathrm{H}$, $0.5 \mathrm{H}, 0.75 \mathrm{H}$ and $\mathrm{H}$ respectively when compared with rigid frame system.

2. For C27 column, 41.53\%, 44.91\%, 42.1\%, $41.27 \%$ and $41.39 \%$ reduction in base column moment is observed core, $1^{\text {st }}$ outrigger at $0.25 \mathrm{H}, 0.5 \mathrm{H}, 0.75 \mathrm{H}$ and Hrespectively when compared withrigid frame system.

3. For C1 column, 41.92\%, 45.27\%, 42.47\%, 41.66\% and $41.78 \%$ reduction in base column moment is observed core, $1^{\text {st }}$ outrigger at $0.25 \mathrm{H}, 0.5 \mathrm{H}, 0.75 \mathrm{H}$ and $\mathrm{H}$ respectively when compared with rigid frame system.

4. $17.96 \%$ and $3.83 \%$ reduction in base core moment at $1^{\text {st }}$ outrigger at $0.25 \mathrm{H}$ and $0.5 \mathrm{H}$. But by providing outrigger at $0.75 \mathrm{H}$ and $\mathrm{H}$ the core moment is increased by $0.65 \%$ and $0.24 \%$ when compared to core system.

\section{$3.32^{\text {nd }}$ Outrigger}

From keeping in view of max reduction in roof displacement the $1^{\text {st }}$ outrigger placed at $0.5 \mathrm{H}$. so, by keeping $1^{\text {st }}$ as constant $2^{\text {nd }}$ outrigger positions are varied i.e. $0.5 \mathrm{H}+0.25 \mathrm{H}$, $0.5 \mathrm{H}+0.75 \mathrm{H}, 0.5 \mathrm{H}+\mathrm{H}$.

Table -4: summary of results from $2^{\text {nd }}$ outrigger system at different location

\begin{tabular}{|c|c|c|c|c|c|}
\hline \multirow[t]{2}{*}{$\begin{array}{l}\text { Position of } \\
\text { outrigger }\end{array}$} & \multicolumn{2}{|c|}{$\begin{array}{l}\text { Roof } \\
\text { displacement } \\
(\mathrm{mm})\end{array}$} & \multicolumn{2}{|c|}{$\begin{array}{l}\text { Base bending } \\
\text { moment of } \\
\text { column }(\mathrm{kN}-\mathrm{m})\end{array}$} & \multirow{2}{*}{$\begin{array}{l}\text { Base } \\
\text { core } \\
\text { moment } \\
(\mathbf{k N}-\mathbf{m})\end{array}$} \\
\hline & $\mathbf{X}$ & $\mathbf{Y}$ & C27 & C1 & \\
\hline $0.5 \mathrm{H}+0.25 \mathrm{H}$ & 148.1 & 154.9 & 1610.1 & 1524.2 & 338290.7 \\
\hline $0.5 \mathrm{H}+0.75 \mathrm{H}$ & 148 & 155.4 & 1707.4 & 1616 & 409577 \\
\hline $0.5 \mathrm{H}+\mathrm{H}$ & 155.6 & 162.4 & 1704.7 & 1613.4 & 407958.5 \\
\hline
\end{tabular}

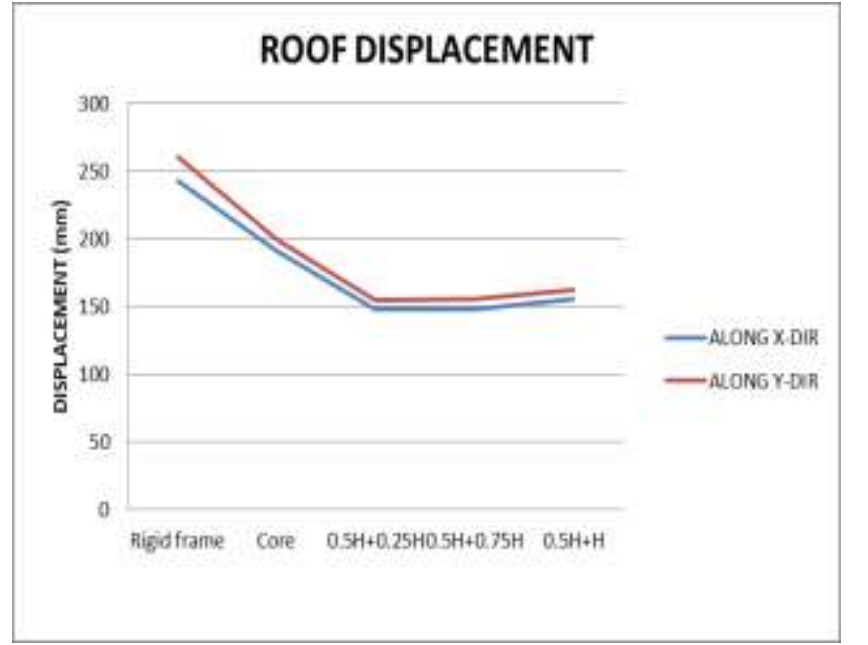

Chart -4: Roof displacement along X and Y direction for rigid frame, core and $1^{\text {st }}$ outrigger at $0.5 \mathrm{H}$ as constant position and $2^{\text {nd }}$ at $0.25 \mathrm{H}, 0.75 \mathrm{H}$ and $\mathrm{H}$

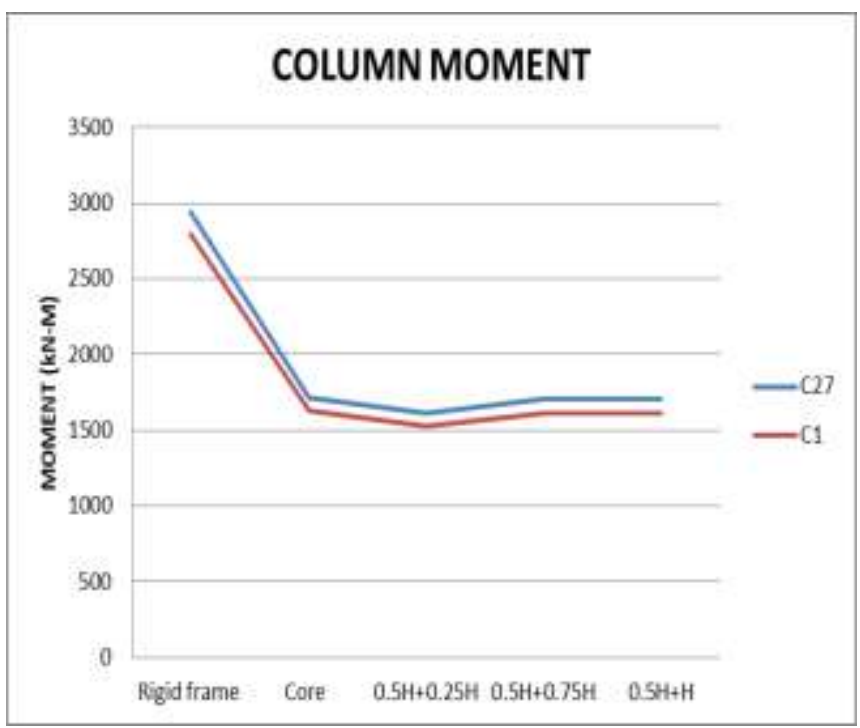

Chart -5: Column moment for C27 and C1 columns

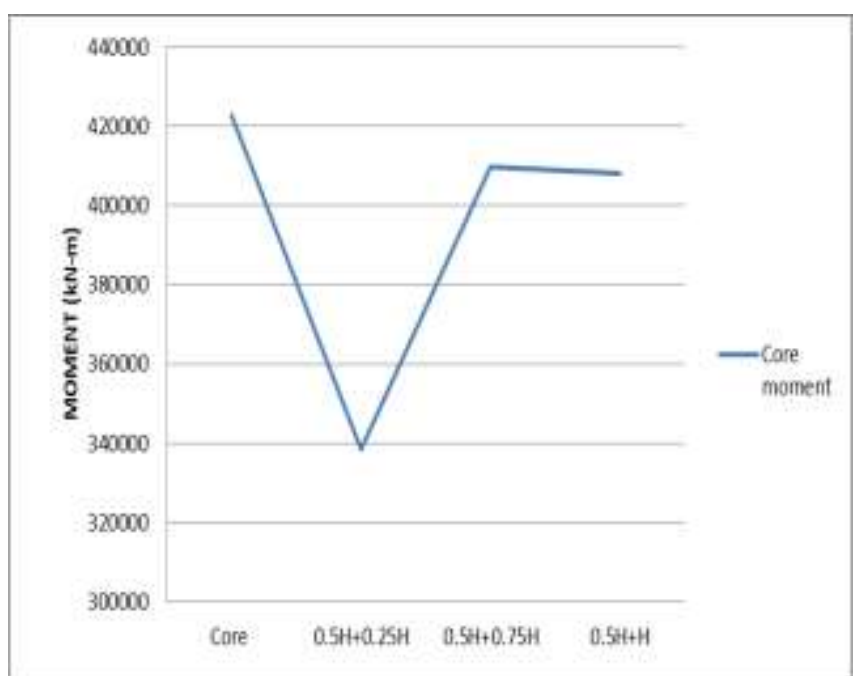

Chart -6: Core moment for core and $1^{\text {st }}$ outrigger at $0.5 \mathrm{H}$ as constant position and $2^{\text {nd }}$ at $0.25 \mathrm{H}, 0.75 \mathrm{H}$ and $\mathrm{H}$ 
1. From chart $-4,39 \%, 39.04 \%$ and $35.91 \%$ reduction in roof displacement along $\mathrm{X}$ direction and $40.65 \%$, $40.45 \%$ and $37.77 \%$ reduction in roof displacement along $\mathrm{Y}$ direction for $1^{\text {st }}$ outrigger at $0.5 \mathrm{H}$ and $2^{\text {nd }}$ outrigger varied at $0.25 \mathrm{H}, 0.75 \mathrm{H}$ and $\mathrm{H}$.

2. For C27 column, $45.18 \%, 41.86 \%$ and $41.95 \%$ and for C1 column $45.55 \%, 42.24 \%$ and $42.33 \%$ reduction of base column moment is noticed when compared with rigid frame system, chart -5 .

3. $20 \%, 3.14 \%$ and $3.52 \%$ reduction in base core moment at $1^{\text {st }}$ outrigger at $0.5 \mathrm{H}$ and $2^{\text {nd }}$ outrigger at $0.25 \mathrm{H}$, $0.75 \mathrm{H}$ and $\mathrm{H}$ respectively when compared to core system, chart -6 .

\section{4 $3^{\text {rd }}$ Outrigger}

From keeping in view of reduction in roof displacement, reduction in column moment and core moment it's clear that the $1^{\text {st }}$ outrigger placed at $0.5 \mathrm{H}$ and $2^{\text {nd }}$ outrigger positions at $0.25 \mathrm{H}$ are effective position. So, by keeping $1^{\text {st }}$ and $2^{\text {nd }}$ as constant $3^{\text {rd }}$ outrigger is varied i.e. $0.5 \mathrm{H}+0.25 \mathrm{H}+0.75 \mathrm{H}$ and $0.5 \mathrm{H}+0.25 \mathrm{H}+\mathrm{H}$.

Table -5: summary of results from $3^{\text {rd }}$ outrigger system at different location

\begin{tabular}{|c|c|c|c|c|c|}
\hline \multirow[t]{2}{*}{$\begin{array}{l}\text { Position of } \\
\text { outrigger }\end{array}$} & \multicolumn{2}{|c|}{$\begin{array}{l}\text { Roof } \\
\text { displacement } \\
(\mathrm{mm})\end{array}$} & \multicolumn{2}{|c|}{$\begin{array}{l}\text { Base bending } \\
\text { moment of } \\
\text { column }(\mathrm{kN}-\mathrm{m})\end{array}$} & \multirow{2}{*}{$\begin{array}{l}\text { Base } \\
\text { core } \\
\text { moment } \\
(\mathbf{k N}-\mathbf{m})\end{array}$} \\
\hline & $\mathbf{X}$ & $\mathbf{Y}$ & C27 & C1 & \\
\hline $\begin{array}{l}0.5 \mathrm{H}+0.25 \\
\mathrm{H}+0.75 \mathrm{H}\end{array}$ & 132.6 & 139.1 & 1617.8 & 1531.6 & 341840 \\
\hline $\begin{array}{l}0.5 \mathrm{H}+0.25 \\
\mathrm{H}+\mathrm{H}\end{array}$ & 138.8 & 145.2 & 1614.4 & 1528.3 & 339564 \\
\hline
\end{tabular}

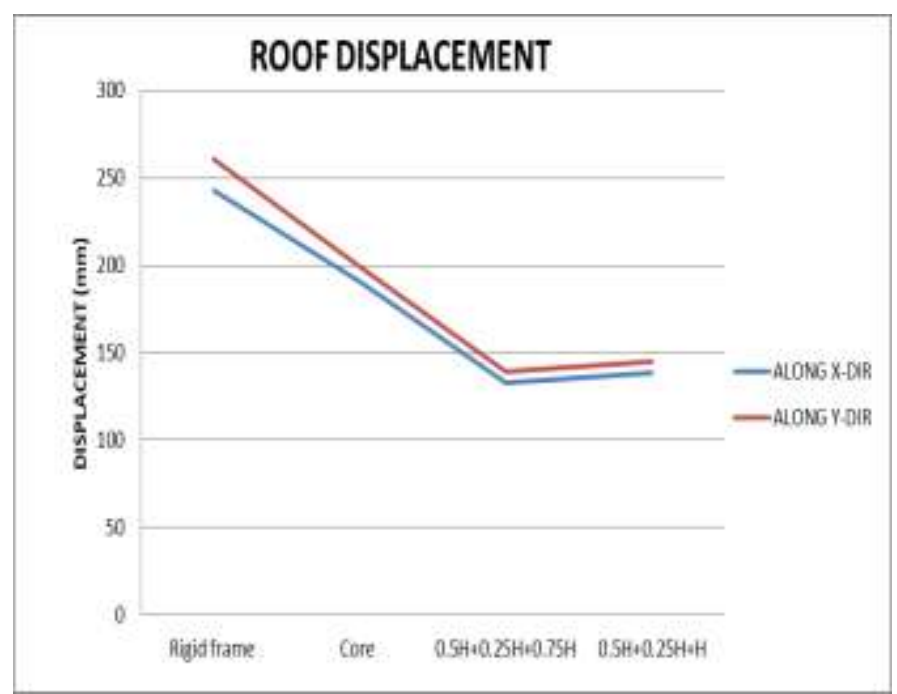

Chart -7: Roof displacement along $\mathrm{X}$ and $\mathrm{Y}$ direction for rigid frame, core, $1^{\text {st }}$ outrigger at $0.5 \mathrm{H}, 2^{\text {nd }}$ at $0.25 \mathrm{Has}$ constant position and $3^{\text {rd }}$ outrigger at $0.75 \mathrm{H}$ and $\mathrm{H}$

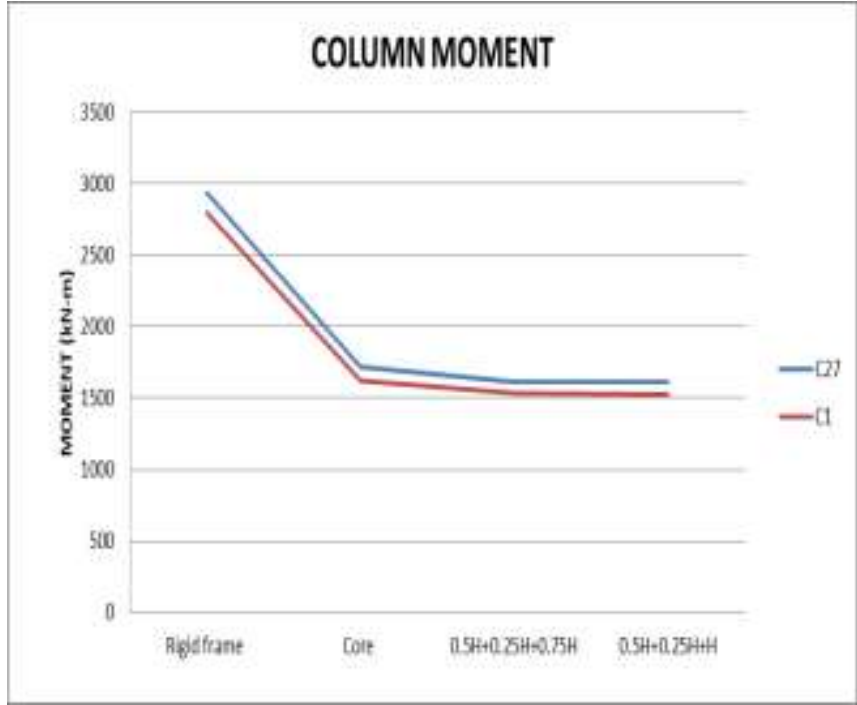

Chart -8: Column moment for C27 and C1 columns

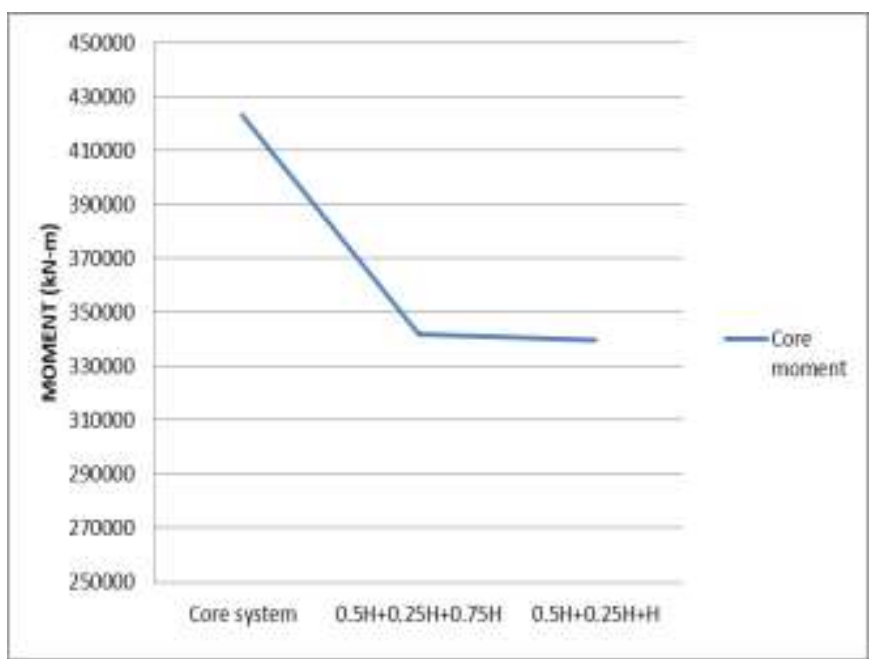

Chart -9: Core moment for core, $1^{\text {st }}$ outrigger at $0.5 \mathrm{H}, 2^{\text {nd }}$ at $0.25 \mathrm{H}$ as constant position and $3^{\text {rd }}$ outrigger at $0.75 \mathrm{H}$ and $\mathrm{H}$

1. From chart $-5,45.38 \%$ and $42.83 \%$ reduction in roof displacement along $\mathrm{X}$ direction and $46.7 \%$, and $44.36 \%$ reduction in roof displacement along $\mathrm{Y}$ direction for $1^{\text {st }}$, $2^{\text {nd }}$ outrigger at $0.5 \mathrm{H}, 0.25 \mathrm{H}$ and $3^{\text {rd }}$ outrigger varied at $0.75 \mathrm{H}$ and $\mathrm{H}$.

2. For C27 column, $44.91 \%$ and $45.03 \%$ and for $\mathrm{C} 1$ column $45.25 \%$ and $45.37 \%$ reduction of base column moment is noticed when compared with rigid frame system, chart -5 .

3. $19.16 \%$ and $19.7 \%$ reduction in base core moment for $1^{\text {st }}, 2^{\text {nd }}$ outrigger at $0.5 \mathrm{H}, 0.25 \mathrm{H}$ and $3^{\text {rd }}$ outrigger varied at $0.75 \mathrm{H}$ and $\mathrm{H}$ respectively when compared to core system, chart -9 .

\section{CONCLUSION}

In this study an attempt is made to assess the seismic behavior of 20 storey high-rise building of rigid frame, core and outrigger structural system. to control roof displacement with minimum base core moment and base column moment. 
Outrigger system depends on the position and numbers of outrigger throughout the height of the building, in present study an effort is made to know the optimum location of outrigger system to control roof displacement with minimum base core moment and base column moment.

With roof displacement as criteria, the optimum location for $1^{\text {st }}, 2^{\text {nd }}$, and $3^{\text {rd }}$ outrigger are $0.5 \mathrm{H}, 0.25 \mathrm{H}$ and $0.75 \mathrm{H}$.

Base column moment and base core moment as criteria, the optimum location for $1^{\text {st }}, 2^{\text {nd }}$, and $3^{\text {rd }}$ outrigger are $0.25 \mathrm{H}$, $0.5 \mathrm{H}$ and $\mathrm{H}$.

The research presented here mainly focus on the seismic behavior of high-rise building of rigid frame, core and outrigger system at different outrigger position. However, future studies should take into account the seismic behavior of different outrigger bracing system for further increase in height of the building.

\section{REFERENCES}

[1] B. Stafford Smith, Irawean Salam (1983) "Formulae for optimum drift resistance of outrigger baced tall building structures": computer and structures, Vol 17, no 1, pp 45-50, 1983.M. Young, The Technical Writer's Handbook. Mill Valley, CA: University Science, 1989. Volume 17, no 1 ,pp 45-50.

[2] Gomanwai-mig ho, arup (2016) "The evolution of outrigger system in tall building": CTBUH research paper. Volume 5, no 1, 21-30

[3] Alpana L. Gawate, J.P. Bhusari (2015) "Behaviour of outrigger structural system for high rise building": International journal of modern trends in engineering.

[4] Krunal Z. Mistry, Proff. Dhruti J. Dhyani (2015) "Optimum outrigger location in outrigger structural system for high rise building": International journal of advance engineering and research. Volume 2, issue 5 .

[5] Surajsangtiani, simon J, satyanayana J, dheerajsangtiani (2017) "Performance of tall building under lateral loads with different type of structural system": International journal of civil engineering and technology. Volume 8, issue 3, pp 1014-1022.

[6] Amit kumar yadav, prof. AnubhavRai (2017) "A seismic comparison of OMRF and SMRF structural system for regular and irregular building" volume 5, issue II.

[7] AkshayKhanorkar, Shurtisukhdeve, S.V Denge, S.P Raut (2016) "Outrigger and belt truss system for tall building to control deflection: A Review" GRD journal - global research and development journal for engineering, volume 1, issue 6 .

[8] Srinivas Suresh Kogilgeri, Beryl Shanthapriya (2015) "A study on behaviour of outrigger system on high rise steel structure by varying outrigger depth" International journal of research in engineering and technology. Volume 4, issue 07.
[9] Shruti B. Sukhdeve (2016) "Optimum position of outrigger in $\mathrm{G}+40 \mathrm{RC}$ building" International journal of science technology and engineering. Volume 2, issue 10 .

[10] Tall Buildings,Structural Systems and Aerodynamic Form Mehmet HalisGünel and HüseyinEmreIlgin.

[11] Tall building structures analysis and design by $B$. Stafford smith and Alex couil.

[12] IS:1893(part 1) - 2002 criteria for earthquake resistant design of structures.

[13] IS13920 : 1993 Ductile detailing of reinforced concrete structures subjected to seismic forces - code of practice.

[14] Saloniapporva, Er. ManjitKaur, Er. AbhishekSachdeva (2018)“CComparission of Fe415 and Fe500 steel in two storey RC building using STAAD Pro" volume 7, issue

\section{BIOGRAPHIES}

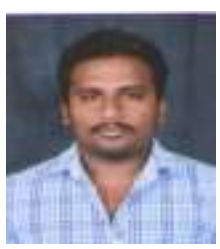

Manoj kumar M, M.Tech student, Department of Civil Engineering,PES college of Engineering, Mandya

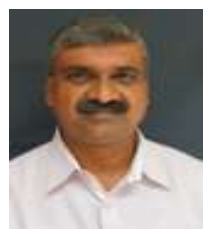

Dr. B. S JayashankarBabu, Professor, Department of Civil Engineering, PES college of Engineering, Mandya 